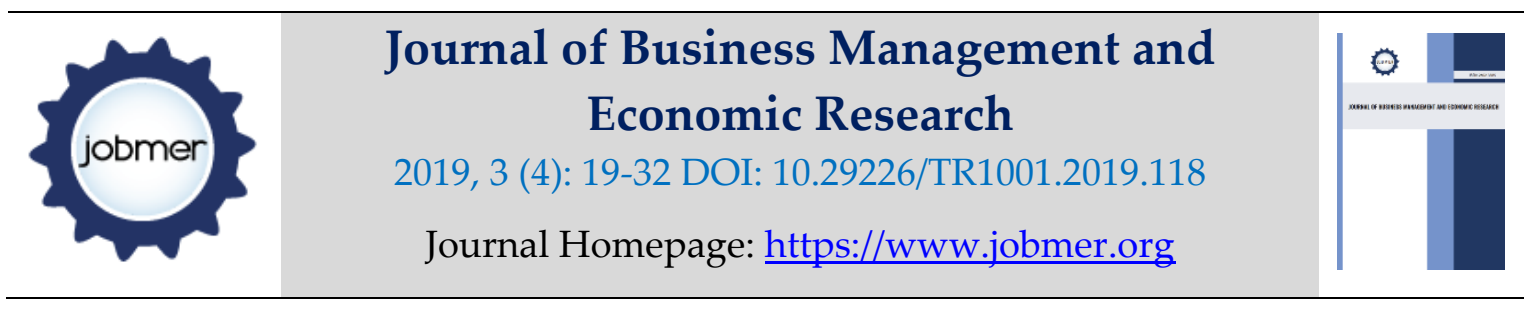

\title{
Customer Brand Engagement and Brand Loyalty Insurance Users in Bali Province
}

\author{
Ni Made Purnami \\ Department of Management, Faculty of Economic and Business, Udayana University, \\ Bali, Indonesia \\ madepurnami@unud.ac.id

\section{Ni Wayan Mujiati} \\ Department of Management, Faculty of Economic and Business, Udayana University, \\ Bali, Indonesia
}

\begin{abstract}
Customer brand engagement is a way for companies to make brands a meaningful part of consumer conversations by increasing consumer engagement to makes brand conversations on social media. This study aims to examine the effect of customer brand engagement, consumer participation, and brand satisfaction on the loyalty of insurance users in Bali Province. Data collection was done by distributing questionnaires to respondents who had participated in the insurance discussion that they used on Facebook with a sample size of 120 people. The analysis technique used is path analysis and Sobel test. The results show that customer brand engagement influences consumer partisipation positively significant, as well as consumer participation that has a positive and significant effect on brand satisfaction, consumer participation has a significant and positive effect on brand loyalty, and brand satisfaction has a significant and positive effect on brand loyalty. The results also show that brand satisfaction is able to mediates the effect of consumer participation on brand loyalty.
\end{abstract}

Keywords: customer brand engagement, brand loyalty

\section{Introduction}

The company continuously strives to interact and maintain long-term relationships with customers and understand the factors that influence customer loyalty. Technological development provides an important role for companies in interacting with customers (Flores and Parraga, 2015). Companies in interacting with consumers currently use social 
media. Customer involvement is seen as an important phenomenon in social media, such as chat, blogs, videos, and brand communities (Brodie et al., 2011a; Dessart et al., 2014). Companies that do not have a customer engagement strategy can lose the opportunity to interact with customers and build long-term relationships .

Customer engagement refers to customer behavior towards a brand or company. Customer engagement in narrow interpretations is often referred to as customer engagement behavior (CEB). Van Doorn et al.(2010) argue that customer engagement behavior includes word of mouth, recommendations, helping other customers to consume better, blogging, writing reviews, and making suggestions to improve the consumption experience. A similar view is explained by Bijmolt et al. (2010) which distinguishes three customer engagements:(1) customer complains ing behavior, (2) word-of-mouth (WOM), and(3) customer co-creation behavior .

Jaakkola \& Alexander (2014) suggest two general types of customer engagement behavior, namely (1) customer communication about the company or brand where customers can get new customers for the company through referral programs with company incentives, or influence other customers, consumers on their own initiative do word -of-mouth, blogging and other forms of customer-to-customer interaction and (2) customer involvement in product development and innovation (customers help increase or develop company offerings by providing feedback, ideas and information, or participating in product design or assembly).

Social media serves as a place for customers to share feelings and thoughts (Schau et al., 2009). More and more companies are investing time and resources in the organizational community on social media and Facebook pages (Shankar and Bhatra, 2009; Vries et al., 2012; Laroche et al., 2012) in the hope that consumers will participate in positively encouraging engagement (Brodie et al., 2011b; Hollebeek, 2011a, 2011b). Customer engagement can have a positive and negative impact on a company (van Doorn et al., 2010; Brodie et al., 2011). Positive customer engagement can include posting positive brand messages on the blog . Negative customer engagement can occur when the customer regulates public action against the company. Thus, viewed from a managerial perspective, the effect of customer engagement can also be positive and negative for a company.

Customer satisfaction is the key in creating customer loyalty (Espejel et al. , 2008). Customer satisfaction is a feeling of pleasure or disappointment that arises from perceptions of the actual performance of the product (Kotler and Keller, 2009: 139). Customer loyalty will arise when 
consumers feel satisfied with the product they consume (Jayaputra, 2009). Increasing customer satisfaction is the responsibility of the company to maintain customer loyalty.

Everyone certainly has a risk to body and soul that needs to be protected from harm that cannot be predicted (Syamsiar, 2013). The existence of these concerns has encouraged someone to seek protection for themselves or their families from the various dangers that threaten to become insurance participants. Like banks, insurance companies operate in a very competitive environment and customers are faced with overwhelming choices (cxm.co.uk) The insurance sector is known to have low transfer barriers, as many as 17 percent of the customer base switch insurance providers every year (Lavik and Schjoll, 2012) This condition is important for insurance companies to gain knowledge about factors in building and maintaining brand loyalty. Brand loyalty shows the desired behavior with respect to the company's brand or service. The need for insurance users at this time wants insurance services that can provide more than the benefits of protection, insurance users also want insurance in line with lifestyle and passion the user.

Innovation in technology-based insurance companies can be used by insurance companies in increasing customer loyalty, especially at this time there has been a lifestyle shift in young people who are increasingly easy to understand information technology. Based on data from the Financial Services Authority (OJK) shows that in the third quarter of 2017 life insurance premium income increased 20 percent to $\mathrm{Rp} 139.27$ trillion. But insurance penetration is still at 2.99 percent of the lower Gross Domestic Product (GDP) compared to other countries in Asia such as Singapore, Malaysia and Thailand which reached more than $5 \%$. In addition, the results of research by the Financial Services Authority (FSA) in 2016, also showed the level of insurance use in Indonesia had only reached 11.81 percent. That is, out of 100 Indonesians, only 11 have insurance policies ( http://www.industry.co.id ).

The purpose of this study is to explain: (1) the influence of customer brand engagement on consumer participation, (2) the influence of consumer participation on brand satisfaction, (3) the influence of consumer participation on brand loyalty, (4) the influence of brand satisfaction on brand loyalty, and (5) the role of brand satisfaction mediates the influence of consumer participation on brand loyalty carried out on insurance users in the Province of Bali based on the phenomenon described above.

Customer Brand Engagement has received a lot of attention from various disciplines such as psychology, organizational behavior and marketing (Gambetti and Grafigna, 2010). Customer 
Brand Engagement is found to be an important element in the online brand community ( Brodie et al, 2011a) and especially social media such as Facebook which is a brand-based community (Gummerus et al., 2012; Habibi et al., 2014). At this time consumers are increasingly proficient in using the internet, organizations that develop online communities through corporate websites, online portals or social networking sites (Zheng et al., 2015). Customer Engagement Marketing is the way a natural company makes a brand a meaningful part of the conversation and life of consumers by increasing customer involvement directly and continuously in shaping brand, experience and community conversations (Kotler \& Armstrong, 2016: 42).

Customer participation is the extent to which a customer places effort and resources in the production process so as to take an active part in consuming and producing value (Nysveen and Pedersen, 2014). Customer participation can be proven in the active role of customers sharing information with the company, customer participation must be considered as a component in co-production. (Ranjan and Read, 2014). Etgar (2008) defines co-production as the participation of customers in one or more activities in the corporate network chain (design, production, delivery, use).

Customer satisfaction is a feeling of pleasure or disappointment that arises because of comparing perceived performance of the product or outcome to brand expectations (Kotler and Keller, 2009: 139). The results of the study by Consuegra et al., 2007 states that satisfied customers will have the desire to repeat previous purchases. Customer satisfaction is created when the company is able to meet the needs of their customers well (Moraga et al ., 2008). Customer satisfaction also affects consumer loyalty (Sondoh et al. , 2007). Consumers feel they have made the right decision when their satisfaction is met (Sulistiyanto and Soliha, 2016).

Loyal customers are those whose enthusiasm for the brand or product they use. Loyalty is the attitude of enjoying a product that is represented in a consistent purchase of the product with the same brand all the time. Loyal consumers will not only use products with the same brand in the future, also recommend products that have been consumed by others ( $\mathrm{Yu}$ and Dean, 2000). The best that can be done by a company in maintaining customer loyalty is by maintaining good relationships with customers, as well as providing rewards to loyal customers (Divet et al. , 2003).

Customers who are loyal to their purchase decisions no longer consider the factors that influence the choice, because it has been embedded in them that the product or service purchased is in line with expectations and able to meet the needs. L ayanan loyalty is the extent 
to which a customer makes repeat purchase behavior of a product, have a positive attitude toward the product (Gremler and Brown, 1996).

\section{Hypothesis}

Customer brand engagement is an important element in the online brand community (Brodie et al, 2011a) and especially social media such as Facebook which is a brand-based community (Gummerus et al., 2012; Habibi et al., 2014). Customer engagement marketing is the way a natural company makes a brand a meaningful part of the conversation and life of consumers by increasing customer engagement directly and continuously in shaping brand conversations, experiences and society (Kotler \& Armstrong, 2016: 42). Some research results related to customer brand engagement show thatcustomer brand engagement positively influences brand satisfaction (Van Doorn et al., 2010; Hollebeek, 2011a) and brand loyalty (Brodie et al., 2011a; Hollebeek, 2011a, 2011b). Other researchers have suggested that customer participation is an antecedent of customer brand engagement (Vivek, 2009; Nysveen and Pedersen, 2014; Ramaswamy and Gouillart, 2010). Based on the description, the proposed hypothesis is :

\section{H1: Customer brand engagement has a positive effect on consumer participation .}

A company creates a platform for value creation that matches the customer's interest to encourage customer participation. Participation can increase brand satisfaction personally and subjectively and influence brand loyalty positively. When customers participate in co-production activities, they tend to share new ideas, suggestions, and problems with the company (Chen et al., 2011). Customer satisfaction is a feeling of pleasure or disappointment that arises because of comparing perceived performance of the product or outcome to brand expectations (Kotler and Keller, 2009: 139). Co-productionhas been found to be a positive predictor of loyalty (Auh et al., 2007; Hosseini, 2013) and satisfaction (Ranjan and Read, 2014; Flores and Vasquez-Parraga, 2015). Customers who are willing to participate in brand activities are considered more satisfied (Bendapudi and Leone, 2003). Based on the description, the proposed hypothesis is:

\section{$\mathrm{H}_{2}$ : Consumer participation has a positive effect on brand satisfaction .}

Customer participation is the extent to which a customer places effort and resources in the production process so as to take an active part in consuming and producing value (Nysveen and Pedersen, 2014). Customer participation can be proven in the active role of customers sharing information with the company, customer participation must be considered as a component inco-production. (Ranjan and Read, 2014). Brand loyalty is one of the keys to 
marketing results. Loyalty refers to the commitment of consumers to consider unique values associated with the brand (Chaudhuri \& Holbrook, 2001). Zhenget al. (2015) states that Facebook user participation has a positive effect on brand loyalty. Based on empirical results in the study, the hypotheses that can be proposed in this study are:

\section{$\mathrm{H}_{3}$ : Consumer participation has a positive effect on brand loyalty.}

In interactive customer social media, customers who are willing to participate in online communities influence brand satisfaction and loyalty. Loyal customers are those whose enthusiasm for the brand or product they use. Loyalty is the attitude of enjoying a product that is represented in a consistent purchase of the product with the same brand all the time. Loyal consumers will not only use products with the same brand in the future, also recommend products that have been consumed by others ( $\mathrm{Yu}$ and Dean, 2000). The results of Jayaputra's (2009) research, Luthfi (2011), and Rachmawati (2014) found that satisfaction has a positive and significant effect on customer loyalty. Based on empirical results in the study, the hypotheses that can be proposed in this study are:

\section{$\mathrm{H}_{4}$ : Brand satisfaction has a positive effect on brand loyalty.}

The mediation role assumed by the brand satisfaction variable on the relationship between customer participation and brand loyalty is tested using the sobel test. The results of Solem's (2013) research show that on social media, customer brand engagement positively influences customer participation, resulting in positive brand satisfaction and loyalty. The results of Solem's (2016) research confirm that brand satisfaction significantly mediates the relationship between customer participation and brand loyalty. Based on empirical results in the study, the hypotheses that can be proposed in this study are:

$\mathrm{H}_{5}$ : Brand satisfaction significantly mediates the influence of consumer participation on brand loyalty

\section{Method}

The research design determines the success in achieving good and useful research results. This study uses a quantitative research design. This research was conducted in Bali Province. The subjects in this study were insurance users in Bali Province who had participated in online brand communities on social media. The population in this study were those who had 
participated in the online brand community. The number of samples in this study were 120 respondents . Responden in this study must have a certain criteria, the characteristics of this sample are: (1) the users of one brand of insurance and live in Bali and (2) s already participated in on Facebook related to their existing insurance.

Based on its nature, the data in this study consisted of quantitative data and qualitative data. Quantitative data in this study is the amount of data from the respondents 'assessment of the research variables, and respondents' characteristics (age and monthly expenditure). Qualitative data in this study include respondent characteristics (name, gender, and education) Based on the source, the data in this study consisted of primary data and secondary data. Primary data in this study were obtained through distributing questionnaires to respondents who were in accordance with the established criteria.Secondary data in this study were obtained by documenting publications and other sources.

Data collection in this study was done by distributing questionnaires to respondents who had met the criteria according to the desired criteria. The questionnaire in this study is a type of questionnaire with a list of closed statements, meaning that the respondent can only answer one or several answer choices prepared by the researcher. The research instrument is used to measure the value of the variables under study (Sugiyono, 2013: 131). The instrument test in this study consisted of: (1) the validity test that the instrument is said to be valid if the correlation coefficient (r ) 30.3 and (2) the reliability test is the instrument said to be reliable if the alpha value is greater than 0.6. The data analysis technique used to solve the problem in this study is path analysis by testing the direct and indirect effects of each variable on the dependent variable accompanied by the Sobel Test. Path analysis is used because this study is designed to estimate the causality relationship on variables that are tiered to the theory.

\section{Results and Discussion}

Respondents were reviewed based on several demographic variables namely gender, age, last education, employment and income / pocket money. In terms of gender, female respondents dominated 62 questionnaires. Based on age criteria, the majority of respondents aged 17-25 years are as many as 60 people. Judging from the latest education, scholars dominate the distribution of respondents as many as 61 people. Based on job criteria, private employees dominate the distribution of respondents as many as 63 people. Judging from income / pocket money, Rp. 2,500,001 to Rp. 4,000,000 per month dominated the distribution of respondents as many as 59 respondents. 
An instrument is said to be valid if Pearson Correlation is greater than 0.30. After testing the validity of the instrument, it was found that all statement indicators in the variable customer brand engagement, consumer participation, brand satisfaction, and brand loyalty had a Pearson Correlation value greater than the number 0.30 so that all indicators in this study had fulfilled the data validity requirements . Reliability testing was carried out on the instrument with the cronbach's alpha coefficient. If the cronbach's alpha value is greater than 0.60 then the instrument is used reliably. The results of the instrument reliability test in this study indicate that all variables are greater than 0.60 so the statement on the questionnaire can be said to be reliable.

Based on the calculation of the standard error value, the results of $\mathrm{e}_{1}$ or standard error of consumer participation variable is $0.768, \mathrm{e}_{2}$ or standard error of variable brand satisfaction. amounting to 0.941 , and e 3 or standard error varia bel brand loyalty of 0.768 . The results of the total determination coefficient are calculated as follows:

$$
\begin{aligned}
\mathrm{R}^{2} \mathrm{~m} & =1-\left(\mathrm{e}_{1}\right)^{2}\left(\mathrm{e}_{2}\right)^{2}\left(\mathrm{e}_{3}\right)^{2} \\
& =1-(0.768)^{2}(0.941)^{2}(0.768)^{2} \\
& =0.692
\end{aligned}
$$

The total determination value of 0.692 means that $69.2 \%$ of the variation in loyalty to insurance users in Denpasar is influenced by variations in customer brand engagement, consumer participation, and brand satisfaction, while the remaining $30.8 \%$ is explained by other factors not included.

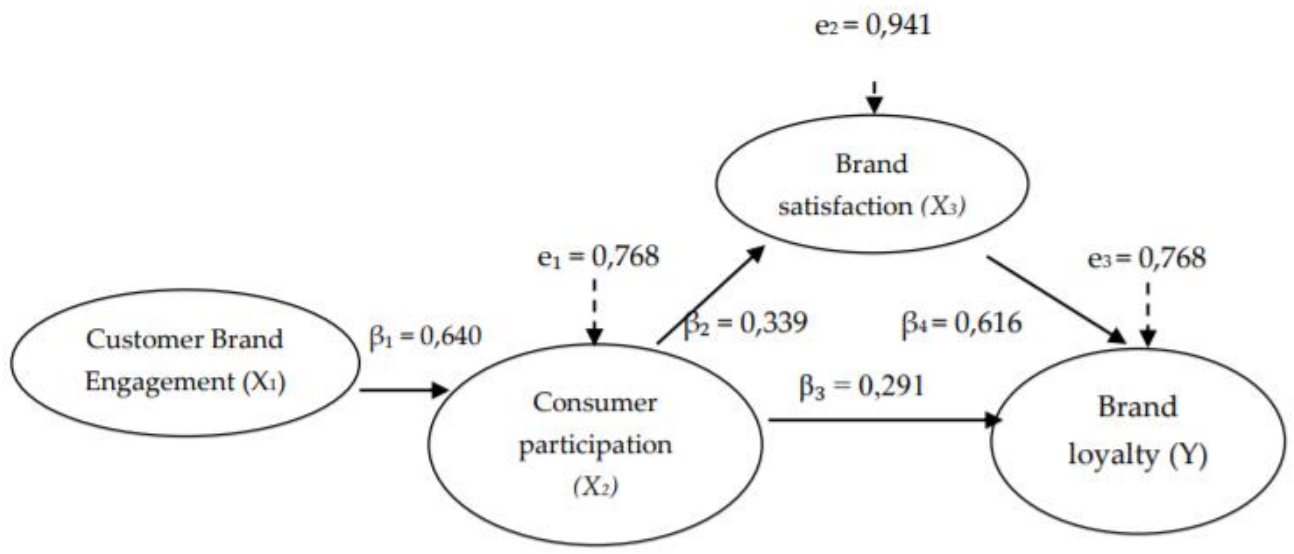

Figure 1. Validation of the Final Path Chart Model

Source: Data processed, 2018 
The structural equation of path analysis in this study is on substructural 1 and substructure 2 as follows:

$\mathrm{X} 2=0.640 \mathrm{X} 1+\mathrm{e}_{1}$

$\mathrm{X} 3=0.339 \mathrm{X} 2+\mathrm{e}_{2}$

$\mathrm{Y}=0,291 \mathrm{X}+0,616 \mathrm{X} 3+\mathrm{e}_{3}$

Based on the final path diagram model in Figure 1, it can be calculated the amount of direct influence, indirect effect, and the total effect between variables. Calculation of influences between variables is summarized in Table 1 .

Table 1. Direct and Indirect Influence and Total Influence and total Influence

\begin{tabular}{cccc}
\hline Variable Influence & $\begin{array}{c}\text { Direct } \\
\text { Influence }\end{array}$ & $\begin{array}{c}\text { Indirect Influence Through } \\
\text { Brand Satisfaction } \\
\left(\boldsymbol{\beta}_{\mathbf{2}} \mathbf{x} \boldsymbol{\beta}_{4}\right)\end{array}$ & Total Influence \\
\hline $\mathrm{X} 1 \rightarrow \mathrm{X} 2$ & 0.640 & - & 0,640 \\
$\mathrm{X} 2 \rightarrow \mathrm{X} 3$ & 0.339 & - & 0.339 \\
$\mathrm{X} 2 \rightarrow \mathrm{Y}$ & 0.291 & 0.207 & 0.498 \\
$\mathrm{X} 3 \rightarrow \mathrm{Y}$ & 0,616 & - & 0.616 \\
\hline
\end{tabular}

Source: Data processed, 2018

Based on Table 1, it can be seen that consumer participation has a direct influence on brand loyalty and indirect influence through brand satisfaction. The magnitude of the indirect influence coefficient can be calculated by multiplying the path coefficient from consumer participation to brand satisfaction with the path coefficient of brand satisfaction to brand loyalty of $0.339 \times 0.616=0.207$. The results of the indirect influence coefficient are smaller than the direct effect $(0.207<0.291)$, so it can be said that the variable of brand satisfaction is as a mediating variable in mediating the effect of consumer participation variables on brand loyalty variables.

Based on the calculation of The Sobel test, obtained the value of $t$ arithmetic of 5, 431 which means greater than $t$ table $(3.486>1.981)$. This result means that brand satisfaction is able to mediate the influence of consumer participation on brand loyalty. Thus, $\mathrm{H}_{5}$ which states that brand satisfaction mediates the effect of consumer participation on brand loyalty is significantly accepted. 


\subsection{Effect of Customer Brand Engagement on Consumer Participation}

The first objective of this research is to explain the influence of customer brand engagement on consumer participation. The test shows that the positive beta coefficient is 0.640 with a significance level of 0.000 (less than 0.05 ) which means that $\mathrm{H}_{1}$ is accepted. The test results show that the variable customer brand engagement has a positive direction and has a significant effect on consumer participation. These results indicate that the higher the customer brand engagement of insurance users in Denpasar City, the higher the level of participation in social media such as Facebook. On the contrary if the customer brand engagement is low, the level of their participation in social media will be low. The results of this study reinforce previous studies that have been carried out by Van Doorn et al. (2010), Hollebeek (2011a), and Solem (2013) who obtained positive and significant results between customer brand engagement and consumer participation.

\subsection{Effect of Consumer Participation on Brand Satisfaction}

The second objective of this study is to explain the effect of consumer participation on brand satisfaction. The test results show that the positive beta coefficient is 0.339 with a significance level of 0.000 (less than 0.05 ) which means that $\mathrm{H}_{2}$ is accepted. These results indicate that consumer participation has a positive and significant effect on brand satisfaction. The interpretation of the results of this study is that the higher the level of participation of insurance users in the City of Denpasar in talking about insurance on social media such as Facebook, the level of satisfaction on their insurance brands will now increase. Conversely, if the participation rate is low, then brand satisfaction will be low. The results of the study are in accordance with previous studies which prove that consumer participation has a positive and significant influence on brand satisfaction as did Ranjan and Read(2014), Flores and VasquezParraga ( 2015), and Bendapudi and Leone ( 2003 ).

\subsection{Effect of Consumer Participation on Brand Loyalty}

The third objective of this research is to explain the effect of consumer participation on brand loyalty. The test results show that the positive beta coefficient is 0.291 with a significance level of 0,000 (less than 0.05 ) so that $\mathrm{H}_{3}$ is accepted. This result means that consumer participation has a positive and significant effect on brand loyalty. The interpretation of these results is that the 
higher the level of participation of insurance users in Denpasar City in the discussion of insurance on social media such as Facebook, then the level of loyalty to their insurance brands will now increase. Conversely, if the participation rate is low, then brand loyalty will be low. The results of this study are in line with several previous studies conducted by Auh et al. (2007), Hosseini (2013), and Zheng et al. (2015) which results that brand satisfaction has a positive and significant effect on brand loyalty .

\subsection{Effect of Brand Satisfaction on Brand Loyalty}

The fourth objective of this study is to explain the influence of consumer participation on brand loyalty. The test results show that the positive beta coefficient is 0.616 with a significance level of 0.000 (less than 0.05 ) so that $\mathrm{H}_{4}$ is accepted. The test results show that the variable of brand satisfaction has a positive direction and has a significant effect on brand loyalty. These results indicate that the higher the level of satisfaction of insurance users in the City of Denpasar on their current insurance brand, the level of loyalty to the brand will increase. Conversely, if the satisfaction level is low, then brand loyalty will be low. The results of this study reinforce some of the previous studies conducted by Jayaputra (2009), Luthfi (2011), and Rachmawati (2014) who found that brand satisfaction has a positive and significant effect on brand loyalty .

\subsection{The Role of Brand Satisfaction Mediates the Effect of Consumer Participation on Brand Loyalty}

The final objective of this study is to explain the role of brand satisfaction in mediating the influence of consumer participation on brand loyalty. The results of testing the indirect effect of consumer participation on brand loyalty through brand satisfaction obtain a smaller coefficient than the direct effect of $0.207<0.291$. Meanwhile, testing with the Sobel test shows that the $t$ count value is 3.486 which is greater than $\mathrm{t}$ table, namely 1.981 so that $\mathrm{H}_{5}$ is accepted. These results indicate that the variable brand satisfaction is able to mediate the influence of consumer participation on brand loyalty significantly.

In connection with these results, it can be interpreted that the participation of insurance users in the City of Denpasar in talks about insurance through social media such as Facebook is able to increase satisfaction with their current insurance brands, resulting in an increase in brand loyalty. The results of this study are consistent with the previous research conducted by Solem 
(2016) which explains that brand satisfaction significantly mediates the relationship between consumer participation and brand loyalty.

\section{Conclusions and Suggestions}

Based on the results of the discussion, several conclusions can be drawn. The first conclusion is that customer brand engagement has a positive and significant effect on consumer participation. The results of this study indicate that the higher the customer brand engagement, the higher the level of participation of insurance users in Denpasar in the discussion of insurance on social media such as Facebook, and vice versa if the customer brand engagement is low, consumer participation will also be lower.

The second conclusion is that consumer participation has a positive and significant effect on brand satisfaction. The results of this study indicate that the higher the level of participation of insurance users in Denpasar in talking about insurance on social media such as Facebook, the higher the satisfaction of their current insurance brands, and vice versa if consumer participation is low, brand satisfaction will also be lower.

The third conclusion is consumer participation positive and significant influence on brand loyalty. These results indicate that the higher the level of participation of insurance users in Denpasar in the discussion of insurance on social media such as Facebook, then the loyalty of their insurance brand will also be higher now, and vice versa if consumer participation is low, brand loyalty will also be lower.

The fourth conclusion is that brand satisfaction has a positive and significant effect on brand loyalty. These results indicate that the higher the level of satisfaction of insurance users in Denpasar in their current insurance brand, the higher brand loyalty will be, and vice versa if brand satisfaction is low, brand loyalty will also be lower. The last conclusion is brand satisfaction able to mediate the influence of consumer participation on brand loyalty. These results indicate that the participation of insurance users in Denpasar in talks on insurance through social media such as Facebook can increase satisfaction with their current insurance brands, resulting in an increase in brand loyalty.

Suggestions that can be recommended based on the results of research, namely customer brand engagement proved to be able to increase the participation of insurance users in Denpasar in talks about insurance on social media such as Facebook. This can be considered by insurance 
providers to shape and pay attention to conversations with consumers on social media about insurance so that it can increase consumer involvement directly in better two-way communication. Consumer participation level the high proved to be able to increase the satisfaction and loyalty of insurance users in Denpasar on their current insurance brand. Therefore, providing a good platform on social media as a place for consumers to talk about insurance should be the concern of insurance providers. When participation or involvement of insurance users through social media is high, then the creation of satisfaction with the insurance brand they use, so that a loyalty arises or in other words consumers will be more loyal to the insurance brand they use.

\section{References}

Auh, S., Bell, S.J., McLeod, C.S. and Shih, E. (2007), Co-production and customer loyalty in financial services, Journal of Retailing, Vol. 83 No. 3, pp. 359-370.

Bendapudi, N. and Leone, R.P. 2003. Psychological implications of customer participation in co-production. Journal of Marketing, Vol. 67 No. 1, pp. 14-28

Bijmolt T.H., Leeflang P.S., Block F., Eisenbeiss M., Hardie B.G., Lemmens A., Saffert P. (2010): Analytics for customer engagement. "Journal of Service Research", Vol. 13(3), pp. 341-356.

Brodie R., Hollebeek L., Jurić B., Ilić A. (2011): Customer engagement: Conceptual domain, fundamental propositions, and implications for research. "Journal of Service Research", Vol. 14(3), pp. 252-271.

Chaudhuri, A. and Holbrook, M.B. 2001. The chain of effects from brand trust and brand affect to brand performance: the role of brand loyalty. Journal of Marketing. Vol. 65 No. 2,pp. 81-93.

Chen, J.S., Tsou, H.T. and Ching, R.K. (2011), Co-production and its effects on service innovation, Industrial Marketing Management, Vol. 40 No. 8, pp. 1331-1346.

Dessart, L., Morgan-Thomas, A. and Veloutsou, C. 2014, Customer engagement in online brand communities: a social media perspective. 9th Global Brand Conference, AM SIG, Hertfordshire, 9-11 April.

Doorn J. van, Lemon K.N., Mittal V., Nass S., Pick D., Pirner P., Verhoef P.C. (2010): Customer engagement behavior: Theoretical foundations and research directions. "Journal of Service Research", Vol. 13(3), pp. 253-266.

Flores, J. and Vasquez-Parraga, A.Z. (2015), "The impact of choice on co-produced customer value creation and satisfaction", Journal of Consumer Marketing, Vol. 32 No. 1, pp. 15-25.

Fuat Firat, A., Dholakia, N. and Venkatesh, A. 1995, Marketing in a postmodern world, European Journal of Marketing, Vol. 29 No. 1, pp. 40-56.

Hollebeek, L.D. 2011a, Demystifying customer brand engagement: exploring the loyalty nexus, Journal of Marketing Management, Vol. 27 No 7/8, pp. 785-807.

Hollebeek, L.D. 2011b, Exploring customer brand engagement: definition and themes, Journal of Strategic Marketing, Vol. 19 No. 7, pp. 555-573.

Jaakkola E., Alexander M. (2014): The role of customer engagement behavior in value co-creation. A service system perspective. "Journal of Service Research", Vol.17(3), pp. 247-261. 
Jayaputra, Arnold. 2009. Pengaruh Kepuasan Kepercayaan dan Komitmen Terhadap Loyalitas Konsumen Telekomunikasi. Business and Management Journal Bunda Mulia, 5(1),pp.6592.

Kotler, Philip \& Armstrong, Gary. 2016. Princioles of Marketing 16E Global Edition. Boston : Pearson

Laroche, M., Habibi, M.R. and Richard, M-O. 2012, "To be or not to be in social media: how brand loyalty is affected by social media?", International Journal of Information Management, Vol. 33, pp. 76-82.

Lavik, R. and Schjøll, A. 2012, "Mobility in different markets, information channels and boarder Trade", Prosjektnotat, SIFO National Institute for Consumer Research, Oslo.

Ramaswamy, V. and Gouillart, F. 2010. Building the co-creative enterprise, Harvard Business Review, Vol. 88 No. 10, pp. 100-109.

Ranjan, K.R. and Read, S. 2014. Value co-creation: concept and measurement, Journal of the Academy of Marketing Science, Vol. 44 No. 3, pp. 290-315.

Shankar, V. and Batra, R. 2009. The growing influence of online marketing communications, Journal of Interactive Marketing, Vol. 23, pp. 285-287.

Schau, H.J., Muñiz, A.M. and Arnould, E.J. 2009. How brand community practices create value, Journal of Marketing, Vol. 73, pp. 30-51.

Solem, Birgit A.A. 2016. Influences of customer participation and customer brand engagement on brand loyalty. Journal of Consumer Marketing. Vl 33 (5), pp. 332-342

Syamsiar, Ratna. 2013. Manfaat dan Mekanisme Penyelesaian Klaim Asuransi Prudential. Fiat Justitia Jurnal Ilmu Hukum. Volume7 No.1, pp. 355-362

Van Doorn, J., Lemon, K.N., Mittal, V. Nass, S., Pick, D., Pirner, P. and Verhoef, P.C. 2010. Customer engagement behavior: theoretical foundations and research directions. Journal of Service Research, Vol. 13 No.3, pp. 253-266.

Vries, L., Gensler, S. and Leeflang, P.S.H. 2012. Popularity of brand posts on brand fan pages: an investigation of the effects of social media marketing. Journal of Interactive Marketing, Vol. 26, pp. 83-91.

Yu, Yi Ting dan Alison Dean. 2000. The Contribution of Emotional Satisfaction To Consumer Loyalty. International Journal of Service Industry Management, 12(3),pp. 234 - 250.

Zheng, Xiabing., Cheung, Christy M.K., Lee, Matthew K.O. and Liang, Liang (2015). Building brand loyalty through user engagement in online brand communities in social networking sites. Information Technology \& People. Vol. 28 No. 1, 2015, pp. 90-106. 